\title{
State of Exception, Law and Economy: A socio-legal approach to the economy of exception in an era of crisis
}

J OSÉ ATILES-OSORIA* DAVID WHYTE*

Atiles-Osoria, J. and Whyte, D., 2018. State of Exception, Law and Economy: A socio-legal approach to the economy of exception in an era of crisis. Oñati Socio-legal Series [online], 8 (6), 808-818. Available from: https://doi.org/10.35295/osls.iisl/0000-0000-0000-0976

\begin{abstract}
Departing from a critical understanding of the relationship between state, law and power, we propose a critical overview of the concept of the state of exception developed by Giorgio Agamben. We emphasise the idea that the principle of legal exceptionality is not as merely used in response to the current crisis in capitalism, but is an enduring and core technique of power used by states to reproduce economic and colonial power relations. Thus, this paper offers three core points of departure from dominant understandings of the state of exception. First, we urge a rupture of the crude opposition between positive law and the state of exception. Second, we argue for a rejection of limited Western concept of (liberal, political) rights. Finally, we argue for an attention to the materiality of power relations, rather than a narrow focus on the power projected by formal institutions of state power.
\end{abstract}

\section{Key words}

Giorgio Agamben; exceptionality; neoliberalism; state power; political economy

\section{Resumen}

Nuestra aproximación al concepto de estado de excepción desarrollado por Giorgio Agamben surge de una comprensión crítica de la relación entre Estado, derecho y poder. Hacemos hincapié en que el principio de excepcionalidad jurídica no es meramente utilizado en respuesta a la actual crisis capitalista, sino que es una técnica de poder central y duradera utilizada por el Estado para reproducir relaciones de poder económicas y coloniales. Esta introducción ofrece tres puntos centrales a partir de la comprensión dominante del estado de excepción: primero, planteamos una ruptura con la oposición cruda entre derecho positivo y estado de excepción; segundo, argüimos en favor del rechazo de la concepción limitada occidental (liberal y política) de los derechos; finalmente, defendemos prestar atención a la materialidad

\footnotetext{
* José Atiles-Osoria is a Postdoctoral Researcher at the Centre for Social Studies of the University of Coimbra and Adjunct professor of Philosophy at the University of Puerto Rico, Mayagüez. Contact details: Colégio de S. Jerónimo, Apartado 308, 3000-995 Coimbra, Portugal. Email address: jose.atiles@upr.edu. ORCID: https://orcid.org/0000-0001-5711-7101

* David Whyte is Professor of Socio-legal studies at the Faculty of Law and Social J ustices at the University of Liverpool. Contact details: Foundation Building, Brownlow Hill, Liverpool, L69 7ZX, UK. Email address: whyted@liverpool.ac.uk ORCID: https://orcid.org/0000-0002-9732-7944
}

\section{(cc) EY-NC-ND}

Oñati International Institute for the Sociology of Law Antigua Universidad s/n - Apdo.28 20560 Oñati - Gipuzkoa - Spain 
de las relaciones de poder, más que al énfasis limitado en el poder protegido por las instituciones formales del poder estatal.

\section{Palabras clave}

Giorgio Agamben; excepcionalidad; neoliberalismo; poder estatal; economía política 


\section{Table of contents / Índice}

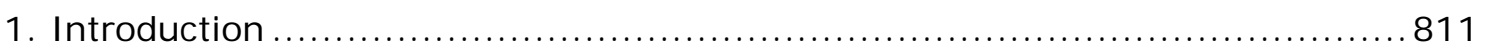

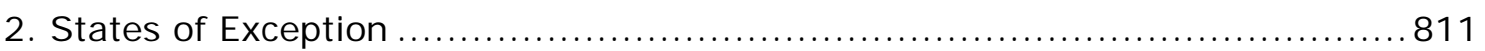

3. A Narrow Conception of "State" and "Law" .................................... 814

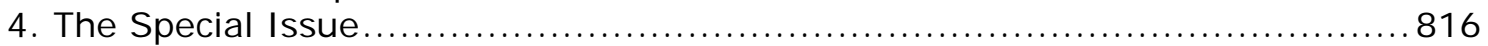

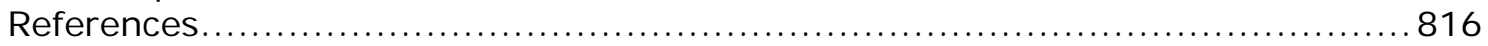




\section{I ntroduction}

The state of exception has become, in the last two decades, a key concept used by social and political theorists to explain periods of crisis. Newspapers, media-outlets, and online platforms inform us, almost every day, of state of emergency declarations, the imposition of exceptional measures or the activation of martial law to deal with economic, social, environmental and political crises, or to tackle scenarios of political violence. In short, we are witnessing a normalization of a state of exception as a technique of political management in contemporary democracies. At the same time, we would argue that the conceptualisation of the state of exception remains underdeveloped. The concept has been narrowly understood as a process in which the suspension of the rule of law and certain constitutional guarantees by the sovereign, have the intention of normalising an "emergency situation" that "threatens" the constitution and/or the normal function of the legal system. Political violence, revolution and riots, the refugee crisis and natural disasters have been the dominant focus of state of exception analyses in the socio-legal and philosophicpolitical traditions.

As we will argue in this introduction, the dominant intellectual perspective of the state of exception, typified by Giorgio Agamben's (2005) development of the concept remains somewhat reductive and limited in its explanatory capacity. Our contention is that, despite the normalization of the state of exception in many jurisdictions (a contention of Agamben's thesis that we agree with), the social-legal, political and economic effects of its implementation remains undertheorized. Even more so, the effects of the state of exception on the people who suffer its implementation most those whose Benjamin (2006) named, in his Theses VIII, "the tradition of the oppressed" - represents an important gap in the conceptualisation of the relationship between exceptionality, law and political economy. In this sense, this special issue aims to expand our understanding of the dispositive of the state of exception in the current socio-legal, political and economic global context. ${ }^{1}$ To do so, it explores the basis of a new epistemological approach in socio-legal studies. This epistemological approach refines Agamben's analysis and systemises the connection between sovereignty, emergency laws and economy.

The special issue thus sets out new ways of thinking about the challenges facing the development of law and quasi-legal mechanism in connection to economic development, democratic governance, corporate power and political mobilisation in the current period. The articles in this special issue aim to disentangle the concept of the state of exception, as well as to portray its entwined relationship with economic and political dominations. At the same time, it seeks to place the history and experiences of those who suffer the most in the face of the exceptional techniques of state power at the core of its reflection.

\section{States of Exception}

In two seminal studies, Giorgio Agamben $(1998,2005)$ demonstrated that the state of exception has ceased to be a dispositive of administration in exceptional situations and has become a routinised dispositive of governmentality, involving a more integral process of social ordering in contemporary Western societies. States of exception are those situations that enable the state/sovereign to invoke the right to suspend the normal rule of law. Normally this occurs under conditions of a declared national emergency involving a security crisis or challenge to the integrity of the state (whether real or imagined). For Agamben, the state of exception represents something fundamental to state power. Starting from this point Agamben shows how the state of exception has become an almost permanent condition in the most powerful and advanced Global North states. Rather than being understood as

\footnotetext{
1 This special issue is based on papers first presented in the workshop State of Exception, Law and Economy: A socio-legal approach to the economic of exception in an era of crisis held at the International Institute for the Sociology of Law, Oñati, the Basque Country, on the $2^{\text {nd }}$ and $3^{\text {rd }}$ of J une, 2016.
} 
aberrations or the extremes at the margins of state power, the worst excesses of arbitrary state power (e.g., Abu Ghraib and Guantanamo) represent the latest manifestations of an ever-present core of state/law/power. In other forms of political and legal governance, the state of exception has visibly become the norm.

The state of exception is not merely a result of bad government, or a pathological condition, but, is [following Schmitt's (2005) famous statement that the sovereign is "he who decides on the state of exception"] the very foundation of state sovereignty. A key aspect of sovereign power that his analysis reveals is the relation between the sovereign and its ability to reproduce the space between law and non-law in which a "secret solidarity between law and anomie" is revealed. There are similarities here with Naomi Klein's (2007) analysis in The Shock Doctrine in the sense that the deliberate creation of chaos is intended to shock a subjugated population into compliance with extreme economic measures. Others have shown that the state of exception works as the legal framework for legitimating corruption and plundering. ${ }^{2}$

For Agamben, therefore, the state of exception represents something fundamental to state power. And it is the intensification of the form that exception takes in contemporary states that reveals something about both the structure of the law and the limits of legal authority. The state of exception normally occurs under the guise of necessity. Agamben argues that the concept of necessity - derived directly from Carl Schmitt (2005) - is the figure that enables the state of exception to appear "as an 'illegal' but perfectly 'juridical and constitutional' measure that is realised in the production of new norms (or of a new juridical order)" [Agamben 2005, 28]. As Hannah Arendt (1977) noted in the context of the Third Reich, suspension of the law is generally justified using a principle of raison d'etat (literally, "reason of state" which is normally equated to the national interest); an overriding concern that requires the state to use extreme means to defend its integrity. For Agamben, the US detention centres of Abu Ghraib and Guantanamo represent the highest stage of development of the state of exception, and rather than being understood as extremes of state power, they portray the most recent manifestations of an ever-present core of state/law/power. The state of exception that is so clearly discernible at Abu Ghraib and Guantanamo therefore acts as a kind of hidden matrix that we can use to chart the course of contemporary politics.

The camp, for Agamben, represents a geopolitical dimension of power. ${ }^{3}$ Rather than merely being understood as an aberration or extreme at the margins of state practice, the camp represents the violent structure of geopolitical power that the paradigm of the state of exception now adopts. The ontological approach adopted by Agamben is significant here, for he argues that the camp should be interpreted in terms of what it tells us about the structure of state power, rather than what it tells us about a specific empirical moment:

Instead of deducing the definition of the camp from the events that took place there, we will ask: What is a camp, what is its juridico-political structure, that such events could take place there? This will lead us to regard the camp, not as a historical fact and an anomaly belonging to the past (even if still verifiable) but in some way as the hidden matrix and nomos of the political space in which we are still living (Agamben 1998, 166)

For Agamben, the state of exception, embodied in the camp, represents the core of state power; the spacial/geopolitical foundation of its sovereignty. This is something very different from a Weberian understanding of state sovereignty - as founded on

\footnotetext{
2 See for example: Whyte's (2010) analysis of the Iraq invasion; Mattei's (2010) analysis of international law and legitimation of plundering of recourses in the Global South; Klein's (2007) analysis of Hurricane Katrina in New Orleans; and Atiles' (forthcoming 2018) analysis of the state of exception and Hurricane Maria in Puerto Rico.

${ }^{3}$ By the camp, Agamben is referring to a space of anomie where civil liberties are erased, and martial law imposed, such as: the Nazi concentration camps, the US detention centres of Abu Ghraib and Guantanamo, but also, the British colonial concentration camps in Kenya as described by Thiong'o (2011, 2013), or the Palestinian refugee camps described by Reynolds (2017).
} 
the exclusive claim to legitimate violence within a constitutionally or legally recognised territory. For Agamben it is not merely the ability to deploy violence, but the rather the ability to impose a particular form-of-law (exception) that denotes sovereign authority. The imposition of this sovereign authority can be inside or outside the rule of law. From this perspective, the relationship between states and a particular rule of law therefore cannot be defined easily; the state of exception exists neither as a lawful space nor as a space of complete lawlessness. Rather a state of exception exists in an indeterminate space or zone of indistinction somewhere between law (in so far as a sovereign authority issues a degree or order that is, by virtue of the fact it has been made by the sovereign, claims a legal source) and nonlaw (in so far as the normal rule of law, or the normal rules of legal procedure have been suspended or erased). The ability of the sovereign to reproduce the space between law and non-law is a moment in which a "secret solidarity between anomie and law" is revealed (Agamben 2005, 71). Power is thus extended through anomic conjunctures in a given state/social system; indeed power is applied through the deliberate creation of anomie.

While the camp portrays the normalisation of geopolitical power and its philosophical, political, and legal redefinition of contemporary democracies, these zones of anomie, also produce a paradigmatic form-of-life, or a biopolitical dimension. In Homo Sacer, Foucault's influence is made explicit in a passage that regrets that lack of development of his idea of the "political double bind". Here, Agamben (1998) argues that what is needed to elaborate our understanding of the state is a development of the interrelation between (objectivising) political techniques and (subjectivising) technologies of the self - a consistent theme in Foucault's centring of a concept of bio-politics. For Agamben it is in the convergence of those realms of power that allows us to get closer to understanding the originary structure of state sovereignty. In order to unlock this basic structure of sovereignty, he seeks to identify a "unitary center in which the political 'double bind' finds its raison d'etre" (Agamben 1998, 6). Ultimately this unitary centre appears as a convergence of "bare" or "naked" life (a life reduced to biological existence without the protection of political status, rights or citizenship) and sovereign power. As this process of convergence unfolds, the state of exception collapses any formal segregation between the individual and the rule of law. In short, bare life is a form-of-life that has been abandoned to the violence of law.

Although Agamben does not develop in detail an analysis of how this is achieved, others adopting a similar approach have. The state of exception, as Aradau (2007) has noted, represents a fundamental shift in the political structure; namely the collapse of law into nomos (the practical requirements necessary to control the space in which legal decisions are taken). Thus, one feature of a state of exception is that the legal authority to take decisions is transferred from political fora to administrative or bureaucratic officials. This is what Butler (2003) has called "governmentality", and/or "the technification of the politics". In Guantanamo, for example, the law functions through the bureaucracy and administrative practices of the prison itself. Key decisions about prisoners or migrants, or any other subject population and how they are to be processed, no longer emanate from legislatures or direct political decisions, but are made by technicians. What happens is that such technically oriented forms of control (which we understand as always political) respond to a particular space according to the requirements of the specific situation, rather than according to any political or legal command. The implications of this transformation are that law imposed by the state of exception is administrative, lacks democratic accountability and is arbitrary and reactionary (Aradau 2007, 496-497). Therefore, the uses of the state of exception create the condition for the depoliticization of politics and it repoliticization into mere technical issues that can be addressed without democratic or public debates. In short, the state of exception has become the legal form of the neoliberal rationality.

To sum up the discussion so far, we understand the contribution that Agamben makes in his development of the concept of the state of exception significantly extends our 
understanding of the co-ordinates of state power beyond the traditional relationship between of law, power, and sovereignty. Indeed, his work develops a complex, twodimensional, manifestation of state/law/power in contemporary politics. On the one hand, a geopolitical dimension expressed through the paradigm of the camp; and, on the other hand, the biopolitical dimension expressed through the paradigm of the bare life. However, as we pointed out above, in this special issue, we are interested in proposing a third dimension ignored by Agamben, but present in Schmitt (2003), that is, the economic dimension of the exceptionality. It is to this third dimension that we now seek to open in the following discussion.

\section{A Narrow Conception of State and Law}

Agamben criticises anarchist and Marxist critiques of the state for their failure to recognise the originary structure of state authority and power. Thus, the theory of the State "is the reef on which the revolutions of our century have been shipwrecked" (Agamben 1998, 12). Yet Agamben's conceptualisation of the state is narrow and incomplete for different reasons: it relies on a formalist understanding of legal and political power. Agamben's fixation with formal process means he is unable to adequately conceptualise the wider dynamics of state power and sovereignty that exist beyond the status ascribed to individuals, or the status ascribed to a particular juncture in the legal order. In order to develop this critique further we set out three points below in which Agamben's theory of the state appears somewhat formalist.

First, the power struggle he analyses is a legal one: the opposition between positive law and the state of exception (which constitutes the undermining of positive law). This is indicated in his consistent argument that state of exception corresponds to a shift in law, from a constitutionally founded civil/criminal legal order to a martial order. Thus, the state of exception that appears in Agamben's work is narrowly concerned with the repressive apparatuses of the state. As a consequence, the rule of law in this formulation is understood in negative, or controlling terms, rather than positive or productive terms (Lemke 2005); as a process of social control rather than social ordering. In doing so, the real social relationships that structure, and are reinforced by, legal relations, are obscured by a concept of a state of exception that fails to constitute human lives in terms of their economic and social reproduction.

For example, racial equality might be formally guaranteed by law, but at the same time is undermined by the real material relations experienced by people of colour in materially unequal societies. ${ }^{4}$ As Mbembe (2003) remains us, Agamben ignores the life experiences of those bodies to whom necropolitics and violence constitute the norm. Thus, Agamben is overly concerned with a liberal concept of rights which privileges formal political and civil rights over and above the limits that economic or social dimensions impose upon rights. Agamben's concern with legal ordering leads to an unnecessary disguising of socio-economic ordering (Whyte 2009). In short, as Reynolds (2017) reminds us, the state of exception is always applied in racialized forms.

The consequence of Agamben's formalism is that law, or the status ascribed by law to people, becomes the determining factor in structuring power relations. However, although law is key in reproducing inequalities, it is not the origin of those inequalities. Ultimately law reproduces inequalities by supporting power relations that are fundamentally determined as unequal through social (as opposed to legal) relations: through land and property ownership, through the working relationships, through patterns of accumulation and consumption, and so on.

Second, the concept of the state of exception as articulated by Agamben is always rooted in a Western idea of rights. Yet in colonial contexts, the state of exception typically takes a rather different form than the imposition of a biopolitics that eradicates human rights or civil liberties. The early colonial regimes, after all, never

\footnotetext{
${ }^{4}$ For an analysis on these lines see Weheliye (2014).
} 
afforded any such liberties to indigenous peoples. Yet as Stephen Morton (2013) has shown, a key manifestation of the state of exception can be found in the European colonies and not necessarily in Global North states or, as Agamben would argue, in the continuity between Roman Empire and European statehood. Therefore, in contradistinction to Agamben, we argue that the colonial origins of the state of exception are present in its everyday applications on the Global North. ${ }^{5}$ Hence, legitimate authority for the expansion of the British and US Empires in their earliest moments was provided by the demarcation of a notional line between the inside/civilised notion of self and the outside/savage notion of self (Venator-Santiago 2006, Santos 2007). As long as the Native American or African was on the other side of the divide, theft of land, brutalisation and genocide could be legitimate. Boiled down to its most simple logic, otherness or being outside of our civilisation justified - in law and in practice - the most extreme measures of violence and expropriation.

A third point of critique that also stems from this overbearing concern with legal rather than socio-economic ordering, identifies a tendency in Agamben's work to limit his scope of analysis to the formal institutions of state power. Thus, there is a tendency to reduce the business of the state to the institutions that are formally public. Markets and market institutions such as corporations are seen as formally separate and outside the state. The danger here is that we reproduce a reductionist view of power in which the relationship between states and capital is simplistically be defined in terms of their antagonistic or external positioning against each other (Tombs and Whyte 2009). Yet late capitalism is marked by a close interdependence of state institutions and corporations. This does not mean that the extent to which "public" and "private" sectors exists as (formally) institutionally distinct is not important. But it does mean that a concept of the state that does not consider the place of capital is likely to miss a great deal in its consideration of state sovereignty. Namely, it is likely to miss what the state of exception means for economic actors (investors, corporations, people "domiciled" in tax havens etc.).

The common questions that those three points raise is: where does the state of exception fit into regimes of capital accumulation (both colonial/Global South and domestic/Global North)? And how might we understand contemporary forms of colonial and economic power as connected to exceptional legal power. Our contention is not that those three points of critique provide reason to invalidate the general approach taken by Agamben. Rather, we see the state of exception as a powerful theoretical tool that can be adapted as a useful means for understanding the relationship between law, economics and sovereignty in the neoliberal era.

Indeed, some preliminary work has been mapped out along those lines (i.e. Ong 2006, Venator-Santiago 2006, Whyte 2009, 2010, Reynolds 2012, Atiles 2016, 2018). The concept of state of exception has been applied by a number of commentators - to understanding government responses to the economic crisis (Lazzarato 2013) - . It is also significant in this respect that Schmitt (2003) coined the term "economic-fiscal state of emergency" to refer to the implementation of this dispositive in the context of economic crises. Benjamin (2006) was well aware of the implication of those uses of exceptionality, when he pointed out that the state of exception is the norm for the tradition of the oppressed. The oppressed named by Benjamin were those who suffered economic and social subjugation, not merely those who suffered formal political repression.

This special issue deals with these scenarios of legal, sociological, economic and philosophic-political challenges imposed by the state of exception as a strategy of governmentality in the local and global political and economic arena. The contributors to this special issue utilise a range of disciplinary epistemological and methodological

\footnotetext{
${ }^{5}$ This is precisely what Césaire (2000) named as the boomerang effect of colonialism and racism. That is, racial and colonial violence was first implemented in the Global South and then return to Europe and the Global North in the form of fascism and totalitarianism.
} 
approaches to develop a perspective that brings the concept of the state of exception to the process of understanding the legal ordering of contemporary capitalism. This is an application of the concept that has hitherto been neglected in socio-legal analysis.

\section{The Special I ssue}

This special issue is divided into three major sub-topics: the colonial state of exception (articles by Atiles, Rodríguez-Maeso, Coleman); the economic state of exception (articles by Rojas and Bernat); and, corporate exceptionalism (articles by Whyte, and Ciocchini and Khoury), each sub-topic providing a distinctive space for debating and focus discussion on the implications of, and possible solutions to, the problems posed by the economy of exception.

Thus, articles by Atiles, Rodríguez-Maeso and Coleman deal with the theoretical and historical analysis of the state of exception in three different contexts of colonial rule. Together they articulate a deep analysis of the legal, political history and constitutional precedents of the development of state of exception in Western countries' colonial projects. Those articles tackle case studies on US-Puerto Rico, European anti-racist policies and corporate violence in Latin America. Articles by Rojas and Bernat show how the state of exception had become a legal dispositive of economic development that instead of promoting just development has led to impoverishment of societies and of their legal, economic and political systems. Together, those articles reveal the connections between the state of exception and neoliberalism in the context of the current economic crisis and how the state of exception is central to the development of economic development and poverty policies. Cases that will be analysed here include the brutal assault on Southern European countries in the name of neoliberal austerity, and the continuum of state violence to secure an economic order in Colombia that was underpinned by an unremitting resort to exceptional powers. Whyte provides an overview of how the concept of the 'corporate citizen' can illuminate a series of exceptional political and legal interventions that at the same time masks class power and secures the economic dominance of a narrow elite, whilst Ciocchini and Khoury show that the Investor-State Dispute Settlement mechanism used in bilateral treaties acts as an exceptional set of rules to neutralise major conflicts around corporate violence.

As a result, this special issue constitutes a unique effort to illuminate what has been forgotten and has remained invisible in the state of exception literature. The special issue aims to rethink the state of exception from below, from the place of those whose lives have been affected by both the economic crises and exceptionality.

\section{References}

Agamben, G., 1998. Homo Sacer: Sovereign Power and Bare Life. Trans.: D. HellerRoazen. Redwood City, CA: Stanford University Press.

Agamben, G., 2005. State of Exception. Trans.: K. Attel. University of Chicago Press.

Aradau, C., 2007. Law Transformed: Guantanamo and the "other" exception. Third World Quarterly [online], 28 (3), 489-501. Available from: https://www.jstor.org/stable/20454942 [Accessed 14 September 2018].

Arendt, H., 1977. Eichmann in Jerusalem: a Report on the Banality of Evil. London: Penguin.

Atiles, J., 2016. Apuntes para abandonar el derecho: Estado de excepción colonial en Puerto Rico. Cabo Rojo: Educación Emergente.

Atiles, J., 2018 (in this issue). Colonial State of Exception as Economic Policy: A Socio-Legal analysis of the Puerto Rican Case. Oñati Socio-legal Series [online], 8 (6), 819-844. Available from: 
https://doi.org/10.35295/osls.iisl/0000-0000-0000-0975 [Accessed 14

September 2018].

Atiles, J., forthcoming 2018. Economic-Financial State of Exception and the Puerto Rican Debt and Fiscal Crisis. Caribbean Voices, Special issue on the Puerto Rican Crisis.

Benjamin, W., 2006. On the Concept of History. In: H. Eiland and M.W. Jennings, eds., Walter Benjamin: Select Writings, Volume 4: 1938 1940. Cambridge, MA: Harvard University Press.

Butler, J., 2004. Precarious Life: The Powers of Mourning and Violence. London: Verso.

Césaire, A., 2000. Discourse on Colonialism. Trans.: J. Pinkham. New York: Monthly Review Press.

Klein, N., 2007. The Shock Doctrine: The Rise of Disaster Capitalism. Toronto, ON: Random House.

Lazzarato, M., 2013. Governing by Debt. Trans.: J.D. Jordan. Cambridge, MA / London: Semiotext.

Lemke, T., 2005. "A Zone of Indistinction" - A Critique of Giorgio Agamben's Concept of Biopolitics. Outlines. Critical Social Studies [online], 7 (1), 3-13. Available from: https://tidsskrift.dk/outlines/article/view/2107/1871 [Accessed 14 September 2018].

Mattei, U., 2010. Emergency-based Predatory Capitalism: The Rule of Law, Alternative Dispute Resolution and Development. In: D. Fassin and M. Pandolfi, eds., Contemporary States of Emergency: The Politics of Military and Humanitarian Interventions. New York: Zone Books, 89-105.

Mbembe, A., 2003. Necropolitics. Public Culture [online], 15 (1), 11-40. Available from: https://doi.org/10.1215/08992363-15-1-11 [Accessed 14 September 2018].

Morton, S., 2013. States of Emergency: Colonialism, Literature and Law. Liverpool University Press.

Ong, A., 2006. Neoliberalism as Exception: Mutations in Citizenship and Sovereignty. Durham, NC / London: Duke University Press.

Reynolds, J., 2012. The Political Economy of State of Emergency. Oregon Review of International Law, 14, 85-130.

Reynolds, J., 2017. Empire, Emergency and the International Law. Cambridge University Press.

Schmitt, C., 2003. The Nomos of the Earth: in the international law of the jus publicum Europaeum. Trans.: G.L. Ulmen. New York: Telos.

Schmitt, C., 2005. Political Theology. Trans.: G. Schwab. University of Chicago Press.

Santos, B. de S., 2007. Beyond Abyssal Thinking: From Global Lines to Ecologies of Knowledges. Revista Crítica de Ciências Sociais [online], 30 (1), 45-89.

Available from: http://www. boaventuradesousasantos.pt/media/pdfs/Beyond_Abyssal_Thinkin g_Review_2007.PDF [Accessed 14 September 2018].

Thiong'o, N.W., 2011. Dreams in a Time of War: A Childhood Memoir. London: Vintage Books.

Thiong'o, N.W., 2013. In the House of the Interpreter: A Memoir. London: Vintage Books. 
Tombs, S., and Whyte, D., 2009. The State and Corporate Crime. In: R. Coleman et al., eds., State, Crime, Power. London: Sage.

Venator-Santiago, C., 2006. From the Insular Cases to Camp X-Ray: Agamben's state of exception and United States territorial law. In: A. Sarat, ed., Studies in Law, Politics and Society, vol. 39, 15-55.

Weheliye, A., 2014. Habeas Viscus: Racializing Assemblages, Biopolitics, and Black Feminist Theories of the Human. Durham, NC / London: Duke University Press.

Whyte, D., 2009. Naked Labour: putting Agamben to work. Australian Feminist Law Journal [online], 31 (1), 57-76. Available from: https://doi.org/10.1080/13200968.2009.10854427 [Accessed 14 September 2018].

Whyte, D., 2010. The Neo-liberal State of Exception in Occupied Iraq. In: W. Chambliss, R. Michalowski and R. Kramer, eds., State Crime in the Global Age. Cullompton: Willan. 